Formatif: Jurnal Ilmiah Pendidikan MIPA

Vol. 9, No. 2, Juni 2019, pp. 117-130

p-ISSN: 2088-351X

e-ISSN: $2502-5457$

DOI: http://dx.doi.org/10.30998/formatif.v9i2.2978

\title{
Development of a Content Management System (CMS) for Mathematics Learning Tools of Mathematics Preservice Teachers
}

\author{
Pengembangan Content Management System (CMS) Perangkat Pembelajaran \\ Matematika bagi Calon Guru Matematika
}

\author{
Etika Khaerunnisa (*) \\ Universitas Sultan Ageng Tirtayasa \\ Aan Subhan Pamungkas \\ Universitas Sultan Ageng Tirtayasa \\ Isna Rafianti \\ Universitas Sultan Ageng Tirtayasa \\ Heni Pujiastuti \\ Universitas Sultan Ageng Tirtayasa \\ Yani Setiani \\ Universitas Sultan Ageng Tirtayasa
}

$\begin{array}{ll}\text { Received: } & \text { November 11, } 2018 \\ \text { Revised: } & \text { February 8, 2019 } \\ \text { Accepted: } & \text { March 18, } 2019\end{array}$

\section{Abstract}

The teacher has an important role in efforts to achieve the learning objectives of the students. In an effort to achieve the learning objectives, the teacher must prepare learning plans that refer to the content standards and learning objectives in each subject. How important is a mathematical learning plan, so that preservice mathematics teachers need to be equipped with the ability to arrange learning tools during lectures. To encourage the skills of prospective teachers in compiling learning tools, one alternative is to integrate TIK. The development of Wordpress Content Management System (CMS) as a learning media is expected to be a learning resource that can be accessed by prospective mathematics teacher students without limited space and time in developing mathematics learning tools which include annual programs, semester programs, syllabus, Learning Implementation Plans (RPP), Student Worksheets (LKS), with the aim of producing a product in the form of learning media that utilizes WordPress Content Management System (CMS) with mathematical learning device content. The research method used Research and Development (R \& D). The research procedure includes seven steps, namely: potential and problems, data collection, product design, design validation, design revision, product testing, and product revision. The instruments used were questionnaires, namely questionnaires for material experts, for media experts, and questionnaires used for limited testing to prospective mathematics teachers in this case students in the mathematics education department at Untirta. the results of the assessment of experts and respondents is equal to $83,8 \%$, meaning that they have met the indicators of success of the products developed.

Keywords: Content Management System, Mathematics Learning Tool, Mathematics Pre Service Teachers

(*) Corresponding Author: etika_kh@untirta.ac.id - 081808229006 


\section{Formatif: Jurnal Ilmiah Pendidikan MIPA}

Vol. 9, No. 2, Juni 2019, pp. 117-130

p-ISSN: 2088-351X

e-ISSN: $2502-5457$

DOI: http://dx.doi.org/10.30998/formatif.v9i2.2978

How to Cite: Khaerunnisa, E., Pamungkas, A.P., Rafianti, I., Pujiastuti, H., \& Setiani, Y. (2019). Development of a content management system (CMS) for mathematics learning tools of mathematics pre service teachers. Formatif: Jurnal Ilmiah Pendidikan. Formatif: Jurnal Ilmiah Pendidikan MIPA, 9 (2): 117-130. http://dx.doi.org/10.30998/formatif.v9i2.2978

\section{PENDAHULUAN}

Peraturan Menteri Pendidikan dan Kebudayaan (Permendikbud) Nomor 22 Tahun 2016 Tentang Standar Proses Pendidikan Dasar dan Menengah mensyaratkan bahwa setiap pendidik pada satuan pendidikan berkewajiban menyusun perencanaan pembelajaran. Perencanaan pembelajaran meliputi kegiatan yang dilaksanakan untuk menentukan pendekatan pembelajaran yang paling baik dilaksanakan agar menimbulkan perubahan dan keterampilan pada peserta didik ke arah yang dikehendakinya, dengan memerhatikan 3 variabel yakni: (1) Kondisi pembelajaran (karakteristik pelajaran dan peserta didik), (2) Metode pembelajaran (pengorganisasian bahan pelajaran, startegi penyampaian, dan pengelolaan kegiatan), (3) Hasil pembelajaran (efektivitas, efisiensi, daya tarik pembelajaran) (Hamzah dan Muhlisrarini, 2014 ).

Penyusunan perencanaan pembelajaran meliputi program tahunan, program semester, silabus, RPP (Rencana Pelaksanaan Pembelajaran), LKS (Lembar Kerja Siswa). Jenis-jenis program pembelajaran tersebut dikenal dengan perangkat pembelajaran. Menurut Suhadi (Susilo, 2007) perangkat pembelajaran adalah sejumlah bahan, alat, media, petunjuk, dan pedoman yang akan digunakan dalam proses pembelajaran. Perangkat pembelajaran yang disusun oleh guru perlu mengacu pada standar isi serta tujuan pembelajaran pada setiap mata pelajaran. Sebagai contoh pada mata pelajaran matematika memiliki tujuan khusus yaitu: (1) Menjelaskan keterkaitan antar konsep dan menggunakan konsep maupun algoritma, secara luwes, akurat, efisien, dan tepat, dalam pemecahan masalah, (2) Menggunakan pola sebagai dugaan dalam penyelesaian masalah, (3) Menggunakan penalaran pada sifat, melakukan manipulasi matematika baik dalam penyederhanaan, maupun menganalisis komponen yang ada dalam pemecahan masalah, (4) Mengomunikasikan gagasan, (5) Melakukan kegiatan motorik menggunakan pengetahuan matematika, (6) Memiliki sikap menghargai kegunaan matematika dalam kehidupan, (7) Memiliki sikap dan perilaku yang sesuai dengan nilai-nilai dalam matematika dan pembelajarannya (Kemendikbud, 2014). Melalui perencanaan pembelajaran matematika yang baik, diharapkan tujuan pembelajaran matematika akan tercapai.

Betapa pentingnya suatu perencanaan pembelajaran matematika, sehingga calon guru matematika perlu dibekali kemampuan menyusun perangkat pembelajaran, yaitu mahasiswa calon guru dituntut untuk mampu mengorganisasikan tujuan, materi pembelajaran, media pembelajaran, dan evaluasi pembelajaran dalam suatu programprogram pembelajaran seperti program tahunan, program semester, silabus, RPP (Rencana Pelaksanaan Pembelajaran), LKS (Lembar Kerja Siswa). Lebih lanjut bahwa setiap guru pada satuan pendidikan berkewajiban menyusun perangkat pembelajaran yang berlangsung secara interaktif, inspiratif, menyenangkan, dan memotivasi siswa untuk berpatisipasi aktif (Devi, 2009). Pentingnya pengembangan perangkat pembelajaran, sehingga mengharuskan calon guru untuk memiliki kemampuan dalam menyusun perangkat pembelajaran sejak dini, sehingga kelak ketika dalam menjalankan profesinya sebagai guru di sekolah dapat melaksanakan proses pembelajaran secara efektif dan efisien yang pada akhirnya mengarah kepada ketercapaian tujuan pembelajaran oleh siswa. Fakta ini menunjukkan bahwa profesi guru merupakan profesi yang penting dan sangat mempengaruhi kualitas pendidikan (Astuti et al, 2019). 
Formatif: Jurnal Ilmiah Pendidikan MIPA

Vol. 9, No. 2, Juni 2019, pp. 117-130

p-ISSN: 2088-351X

e-ISSN: 2502-5457

DOI: http://dx.doi.org/10.30998/formatif.v9i2.2978

Pentingnya calon guru matematika dalam menyusun perangkat pembelajaran, tidak didukung dengan kenyataan yang ada, bahwa berdasarkan pengamatan pada mahasiswa calon guru matematika Jurusan Pendidikan Matematika Universitas Sultan Ageng Tirtayasa (Untirta) yang sedang melakukan Praktik Kerja Lapangan di sekolahsekolah melalui perangkat pembelajaran yang mereka buat, masih dalam taraf meniru apa yang dibuat oleh guru pamong di sekolah, tidak ada proses kreativitas dalam mengembangkan perangkat pembelajaran. Sebagai contoh dalam LKS hanya tersedia pertanyaan tertutup (hanya memiliki satu jawaban). Dalam RPP aktivitas pembelajaran tidak eksploratif (tidak ada kegiatan penyelidikan). Dengan kenyataan seperti itu, dapat dibayangkan bahwa proses pembelajarannya tidak mengaktifkan siswa. Hal tersebut sangat memprihatinkan, bila tidak segera diupayakan untuk memperbaikinya. Padahal, menurut Majid (2013) perangkat pembelajaran seperti LKS dalam kegiatan belajar mengajar dapat dimanfaatkan pada tahap penanaman konsep (menyampaikan konsep baru) atau pada tahap pemahaman konsep [tahap lanjutan dari penanaman konsep])

Oleh karena itu, dengan adanya permasalahan ini maka mahasiswa calon guru perlu mengetahui bagaimana mengembangkan perangkat pembelajaran, untuk mendorong minat mahasiswa calon guru matematika dalam upaya membekali mahasiswa agar memiliki keterampilan menyusun perangkat pembelajaran, salah satu alternatif yaitu dengan adanya sumber belajar yang dapat digunakan oleh mahasiswa calon guru matematika. Berdasarkan hasil studi pendahuluan pada mata kuliah rumpun pembelajaran di jurusan pendidikan matematika Untirta, tampak bahwa sumber belajar yang digunakan oleh dosen dalam membekali mahasiswa dalam merancang perangkat pembelajaran hanya sebatas pada contoh perangkat yang diberikan oleh dosen pada perkuliahan tatap muka di kelas melalui bahan tayang serta buku teks serta contoh perangkat pembelajaran yang dapat diakses oleh mahasiswa melalui pemanfaatan internet yang dikembangkan oleh orang lain. Dengan kemudahan dalam mengakses contoh perangkat pembelajaran ini memungkinkan mahasiswa memperoleh informasi dari berbagai sumber belajar, tetapi kelemahan yang tampak di antaranya kevalidan perangkat yang dikembangkan belum tentu sesuai dengan prinsip kurikulum yang berlaku. Untuk memperkaya sumber belajar bagi mahasiswa, maka perlu upaya pengembangan sumber belajar berupa media pembelajaran yang mengintegrasikan teknologi informasi dan komunikasi dalam menyajikan contoh perangkat pembelajaran matematika sebagai sumber belajar bagi mahasiswa calon guru matematika. Dengan cara mengembangakan media pembelajaran ini diharapkan pengembangan perangkat pembelajaran yang nantinya disusun oleh mahasiswa calon guru matematika sesuai dengan prinsip kurikulum yang berlaku di sekolah serta karakteristik siswa.

Seiring perkembangan teknologi informasi dan komunikasi yang semakin meningkat, kebutuhan akan suatu pola pembelajaran berbasis teknologi informasi dan komunikasi (TIK) tidak dapat dipisahkan. Hal ini didukung Permendiknas Nomor 41 tahun 2007 tentang standar proses telah ditetapkan bahwa prinsip-prinsip perencanaan pembelajaran disusun dengan mempertimbangkan penerapan TIK secara terintegrasi, sistematis, dan efektif sesuai dengan situasi dan kondisi (Depdiknas, 2007). Penerapan pola pembelajaran berbasis TIK tidak terlepas dengan pemanfaatan komputer dalam pembelajaran untuk mencapai tujuan pembelajaran.

Perkembangan TIK melahirkan adanya sisi ketergantungan manusia. Saat ini, manusia sangat bergantung pada teknologi. Hasil penelitian yang dilakukan Sudiana (2014) yang menunjukan bahwa menunjukan 91\% mahasiswa di jurusan pendidikan Matematika Untirta aktif menggunakan internet sebagai media komunikasinya. Kondisi tersebut potensial untuk dikembangkan media pembelajaran yang berbasis internet, sehingga sumber belajar bagi mahasiswa calon guru dalam penyusunan perangkat 


\section{Formatif: Jurnal Ilmiah Pendidikan MIPA}

Vol. 9, No. 2, Juni 2019, pp. 117-130

p-ISSN: 2088-351X

e-ISSN: 2502-5457

DOI: http://dx.doi.org/10.30998/formatif.v9i2.2978

pembelajaran matematika tidak hanya sebatas bersumber pada dosen, melainkan melalui media pembelajaran yang dapat diakses di manapun dan kapanpun tanpa terbatas ruang dan waktu. Pemakaian media pembelajaran dapat membangkitkan keinginan dan minat yang baru, membangkitkan motivasi dan rangsangan belajar.

Media pembelajaran yang dikembangkan dengan memanfaatkan content management system (CMS), yang dimaksudkan untuk memberikan pengetahuan dan keterampilan kepada mahasiswa calon guru dalam menyusun perangkat pembelajaran matematika. Kegunaan CMS adalah untuk mempermudah user membangun sebuah situs website dan juga memudahkan dalam mengedit konten (Iqbal, 2009). Pemanfaatan CMS dalam pembelajaran sudah mulai banyak dikembangkan dan terdapat beberapa bentuk $L M S$ yang ditawarkan antara lain wordpress. WordPress adalah sebuah aplikasi sumber terbuka (open source) yang sangat populer digunakan sebagai mesin blog (blog engine). Selain sebagai blog, WordPress juga mulai digunakan sebagai sebuah CMS (Content Management System) karena kemampuannya untuk dimodifikasi dan disesuaikan dengan kebutuhan penggunanya.

Pemilihan CMS Wordpress sebagai media pembelajaran diharapkan menjadi sumber belajar yang dapat diakses oleh mahasiswa calon guru matematika dalam mengembangkan perangkat pembelajaran matematika yang meliputi program tahunan, program semester, silabus, RPP, LKS, video pembelajaran. Berdasarkan latar belakang tersebut, peneliti tertarik untuk mengembangkan CMS Perangkat Pembelajaran Matematika.

\section{METODE}

Metode penelitian dalam pengembangan Content Management System (CMS) perangkat pembelajaran matematika bagi calon guru matematika ini adalah Research and Development $(R \& D)$ karena $R \& D$ merupakan metode penelitian yang digunakan untuk menghasilkan produk tertentu (Sugiyono, 2010).

Prosedur penelitian yang akan digunakan oleh peneliti adalah prosedur penelitian yang dikembangkan oleh Sugiyono. Sugiyono (2010) membagi langkah-langkah penelitian dan pengembangan ke dalam sepuluh tahap sebagai berikut: (1) Identifikasi masalah, (2) Pengumpulan informasi, (3) Desain produk, (4) Validasi desain, (5) Perbaikan desain, (6) Ujicoba produk, (7) Revisi produk, (8) Uji coba pemakaian, (9) Revisi produk tahap akhir, dan (10) Produksi masal. Berikut ini adalah langkah-langkah model pengembangan media pembelajaran digambarkan seperti pada gambar 1 (Sugiyono, 2010).



Gambar 1. Langkah Metode Penelitian Dan Pengembangan 


\section{Formatif: Jurnal Ilmiah Pendidikan MIPA}

Vol. 9, No. 2, Juni 2019, pp. 117-130

p-ISSN: 2088-351X

e-ISSN: 2502-5457

DOI: http://dx.doi.org/10.30998/formatif.v9i2.2978

Penelitian ini melibatkan tujuh langkah. Hal ini dikarenakan produk yang dihasilkan hanya diujicobakan dalam skala kecil. Ketujuh langkah tersebut, yaitu: potensi dan masalah, pengumpulan data, desain produk, validasi desain, revisi desain, uji coba produk, dan revisi produk.

Instrumen yang akan digunakan dalam penelitian ini berupa kuesioner (angket). Angket yang akan digunakan dalam penelitian ini terdiri atas 3 angket, yaitu angket untuk ahli materi, untuk ahli media, dan angket yang digunakan untuk uji terbatas kepada calon guru matematika dalam hal ini mahasiswa di jurusan pendidikan matematika Untirta.

Untuk mendeskripsikan hasil angket repsonden maka hasilnya dihitung dengan menggunakan rumus berikut:

Keterangan:

$$
p=\frac{\text { Skor mentah }}{\text { Skor Ideal }} \times 100 \%
$$

Skor mentah : Jumlah skor jawaban respoden

Skor ideal : Jumlah skor jawaban tertinggi

$\mathrm{p}$

: Persentase

Penafsiran atau interpretasi dengan kategori persentase berdasarkan kriteria klasifikasi skala yang dimodifikasi dari Riduwan (2013) sebagai berikut:

Tabel 1.Kriteria Interpretasi Skor Angket

\begin{tabular}{ll}
\hline \multicolumn{1}{c}{ Kriteria } & \multicolumn{1}{c}{ Klasifikasi } \\
\hline $0 \% \leq p \leq 20 \%$ & Sangat Lemah \\
$20 \%<p \leq 40 \%$ & Lemah \\
$40 \%<p \leq 60 \%$ & Cukup \\
$60 \%<p \leq 80 \%$ & Kuat \\
$80 \%<p \leq 100 \%$ & Sangat Kuat \\
\hline
\end{tabular}

Dari jarak interval yang telah didapat, kemudian dapat disusun klasifikasi berdasarkan skor jawaban responden, sehingga dapat mengetahui klasifikasi atau kategori sikap responden terhadap media pembelajaran berbasis CMS. Menurut Tim Puslitjaknov (2008), produk pengembangan dikatakan layak dengan presentasi kelayakan minimal $70 \%$ dari uji ahli. Maka indikator keberhasilan dari penelitian ini yaitu terciptanya produk berupa CMS perangkat pembelajaran matematika bagi calon guru matematika dengan kriteria menurut ahli materi 70\%, ahli media $70 \%$, serta sikap calon guru matematika pada uji skala terbatas sebasar $70 \%$.

\section{HASIL DAN PEMBAHASAN}

\section{Hasil}

Tahap-tahap pengembangan tersebut akan dijelaskan sebagai berikut.

\section{Potensi dan Masalah}

Penelitian dapat berawal dari adanya potensi dan masalah (Sugiyono, 2010). Potensi adalah segala sesuatu yang bila didayagunakan akan memilliki nilai tambah, sedangkan masalah adalah penyimpangan antara apa yang diharapkan dengan yang terjadi. 


\section{Formatif: Jurnal Ilmiah Pendidikan MIPA}

Vol. 9, No. 2, Juni 2019, pp. 117-130

p-ISSN: 2088-351X

e-ISSN: 2502-5457

DOI: http://dx.doi.org/10.30998/formatif.v9i2.2978

Seiring perkembangan teknologi informasi dan komunikasi yang semakin pesat, kebutuhan akan suatu pola pembelajaran (pendidikan) berbasis teknologi informasi dan komunikasi (TIK) tidak terelakan lagi. Penerapan pola pembelajaran berbasis teknologi informasi dan komunikasi tidak terlepas dengan pemanfaatan komputer dalam pembelajaran. Perkembangan TIK melahirkan adanya sisi ketergantungan manusia. Saat ini, manusia sangat bergantung pada teknologi. Kondisi ini menunjukkan bahwa saat ini dibutuhkan bahan ajar selain buku teks yang sesuai dengan perkembangan dan tuntutan zaman. Hal lain yang memperkuat media pembelajaran berbasis internet adalah hasil studi literatur beberapa penelitian melaporkan bahwa buku teks belum optimal sehingga bahan ajar interaktif dapat membantu siswa untuk aktif, mandiri, dan bertanggung jawab dalam proses pembelajaran (Rafianti, 2018).

Kondisi tersebut potensial untuk dikembangkannya media pembelajaran berbasis internet, sehingga sumber belajar bagi mahasiswa calon guru dalam penyusunan perangkat pembelajaran matematika tidak hanya sebatas bersumber pada dosen, melainkan melalui media pembelajaran yang dapat diakses di manapun dan kapanpun tanpa terbatas ruang dan waktu. Pemakaian media pembelajaran dapat membangkitkan keinginan dan minat yang baru, membangkitkan motivasi dan rangsangan belajar. Berdasarkan hasil penelitian yang telah dilakukan oleh Rolisca dan Achadiyah (2014) menunjukkan bahwa dengan adanya media teknologi informasi komunikasi maka akan memudahkan komunikan (guru) dan komunikator (siswa) dalam melakukan proses pembelajaran.

Dari potensi dan masalah yang telah dipaparkan di atas menunjukkan bahwa adanya kebutuhan terhadap media pembelajaran. Oleh karena itu, dalam penelitian ini akan dikembangkan media pembelajaran matematika berbasis Content Management System (CMS) perangkat pembelajaran matematika bagi calon guru matematika yang diharapkan dapat mengatasi kelemahan dalam media pembelajaran cetak. Media pembelajaran yang dikembangkan dengan memanfaatkan CMS, yang dimaksudkan untuk memberikan pengetahuan dan keterampilan kepada mahasiswa calon guru dalam menyusun perangkat pembelajaran matematika.

\section{Pengumpulan Data}

Setelah mengetahui kebenaran mengenai potensi dan masalah, selanjutnya perlu dikumpulkan berbagai data sebagai bahan informasi yang dapat digunakan sebagai bahan perencanaan produk media pembelajaraan yang diharapkan dapat mengatasi masalah. Pada tahap ini dilakukan pengumpulan bahan seperti materi pembelajaran yang menunjang perencanaan pembelajaran matematika seperti hakikat perencanaan pembelajaran matematika, matematika sekolah, pendekatan, dan model pembelajaran matematika, pendidikan karakter, contoh program tahunan, contoh program semester, contoh silabus, contoh RPP, dan lain-lain yang diperlukan untuk tahap berikutnya. Bahan yang diperlukan dalam tahap ini diperoleh dari sumber-sumber seperti internet, bukubuku referensi pendukung, serta hasil kinerja mahasiswa dalam menyusun program tahunan, program semester, silabus, dan RPP.

\section{Desain Produk}

Desain media yang akan dikembangkan sebagai media pembelajaran berbasis Content Management System (CMS) adalah sebagai berikut:

Nama produk : Perangkat Pembelajaran Matematika SMP

Halaman web : matematikauntirta.wordpress.com 


\section{Formatif: Jurnal Ilmiah Pendidikan MIPA}

Vol. 9, No. 2, Juni 2019, pp. 117-130

p-ISSN: 2088-351X

e-ISSN: 2502-5457

DOI: http://dx.doi.org/10.30998/formatif.v9i2.2978

$\begin{array}{lll} & & \\ \text { Mata Kuliah } & : & \text { Perencanaan Pembelajaran Matematika } \\ \text { Pengguna } & : & \text { Mahasiswa jurusan pendidikan matematika Untirta } \\ \text { Isi Media } & : & \begin{array}{l}\text { Teori perencanaan pembelajaran, power point pendekatan } \\ \text { pembelajaran matematika, contoh perangkat pembelajaran } \\ \text { matematika SMP, Video pembelajaran matematika SMP }\end{array}\end{array}$

Berikut tampilan Content Management System (CMS) perangkat pembelajaran matematika bagi calon guru matematika.

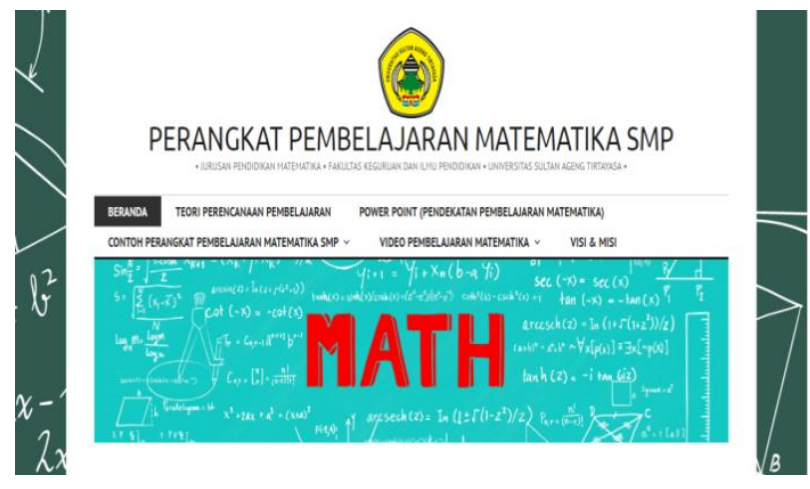

Gambar 2. Tampilan media pembelajaran

\section{Validasi Desain}

Validasi desain merupakan proses kegiatan untuk menilai apakah rancangan produk secara rasional akan lebih efektif dari produk sebelumnya atau tidak. Dikatakan rasional karena validasi masih bersifat pemikiran rasional, belum fakta lapangan (Sugiyono, 2015).

Validasi produk dapat dilakukan dengan cara menghadirkan beberapa pakar atau tenaga ahli yang sudah berpengalaman untuk menilai produk yang telah dirancang tersebut (Sugiyono, 2015). Setiap pakar akan diminta untuk menilai desain tersebut, sehingga selanjutnya dapat diketahui kelemahan dan kekuatannya. Dalam proses ini, peneliti menghadirkan empat orang ahli, ahli tersebut antara lain satu orang ahli materi, dan satu orang ahli media.

\section{a. Ahli Materi}

Ahli Materi dalam penelitian ini terdiri dari satu ahli, yang mana ahli tersebut diharapkan dapat memberikan penilaian awal dan masukan mengenai media pembelajaran berbasis CMS ditingkat Perguruan Tinggi yang dikembangkan dari sudut pandang pendidikan.

Berdasarkan hasil penilaian ahli materi diperoleh hasil bahwa media pembelajaran berbasis CMS perangkat pembelajaran matematika sudah tergolong kuat, walaupun masih diperlukan perbaikan berdasarkan saran dan tanggapan ahli. Adapun komentar dan saran dari ahli adalah sebagai berikut.

Tabel 2. Saran Ahli Materi

\begin{tabular}{cl}
\hline Ahli & \multicolumn{2}{c}{ Komentar/saran } \\
\hline Ahli Materi & a. \\
& Agar terpenuhi kriteria sistematika yang runut, logis, dan \\
& jelas maka urutan judul pada media pembelajaran perlu dikaji \\
& kembali seperti penyajian materi secara umum, urutan \\
& menjadi materi pendekatan pembelajaran, contoh perangkat
\end{tabular}


Formatif: Jurnal Ilmiah Pendidikan MIPA

Vol. 9, No. 2, Juni 2019, pp. 117-130

p-ISSN: 2088-351X

e-ISSN: 2502-5457

DOI: http://dx.doi.org/10.30998/formatif.v9i2.2978

pembelajaran untuk beberapa topik dalam pembelajaran matematika.

b. Agar tujuan pembelajaran jelas (reabilitas dan terukur), maka perlu dicantumkan tujuan pembelajaran dalam media pembelajaran.

c. Agar terpenuhi kriteria kebenaran materi secara teori dan konsep, maka perlu dicantumkan daftar pustaka di akhir penyajian materi.

d. Perlu ditambahkan evaluasi agar dapat mengukur kemampuan atau pencapaian mahasiswa, dan mendeskripsikan kesesuaian antar materi, media dan evaluasi dengan tujuan pembelajaran.

Berdasarkan validasi ahli materi maka produk media pembelajaran yang dikembangkan memiliki presentase penilaian sebesar 83,9\% dengan kategori kuat sehingga baik untuk digunakan sebagai media pembelajaran.

\section{b. Ahli Media}

Ahli media dalam penelitian ini terdiri dari satu ahli, yang mana ahli tersebut diharapkan dapat memberikan memberikan penilaian awal dan masukan secara objektif mengenai tampilan media dan kelayakan aplikasi dalam media pembelajaran berbasis CMS. Hasil validasi satu orang ahli media disajikan pada tabel berikut ini.

Berdasarkan hasil penilaian ahli media diperoleh hasil bahwa media pembelajaran berbasis CMS perangkat pembelajaran matematika sudah tergolong kuat, walaupun masih diperlukan perbaikan berdasarkan saran dan tanggapan ahli. Adapun komentar dan saran dari ahli adalah sebagai berikut.

Tabel 3. Saran Ahli Media

\begin{tabular}{|c|c|}
\hline Ahli & Komentar/saran \\
\hline Ahli Media & $\begin{array}{l}\text { a. Agar media pembelajaran memenuhi kriteria unggul (memiliki } \\
\text { kelebihan dibanding media pembelajaran lain ataupun dengan } \\
\text { cara konvensional) disarankan materi tidak hanya dapat dilihat } \\
\text { tetapi dapat diunduh oleh pengguna. } \\
\text { b. Agar media pembelajaran memenuhi kriteria komunikatif: unsur } \\
\text { visual dan audio mendukung materi ajar, agar mudah dicerna } \\
\text { oleh mahasiswa sebaiknya disajikan video pembelajaran yang } \\
\text { menggambarkan pendekatan pembelajaran matematika. } \\
\text { c. Agar media pembelajaran memenuhi kriteria Unsur visual } \\
\text { bergerak dan dapat dimanfaatkan untuk menyimulasikan materi } \\
\text { ajar dan mengilustrasikan materi secara nyata maka perlu } \\
\text { disajikan beberapa video pembelajaran matematika. } \\
\text { d. Agar media pembelajaran memenuhi kriteria pada unsur audio } \\
\text { maka perlu diperkaya dengan ilustrasi musik/sound. }\end{array}$ \\
\hline
\end{tabular}

Berdasarkan validasi ahli media maka produk media pembelajaran yang dikembangkan memiliki presentase penilaian sebesar $85,71 \%$ dengan kategori kuat sehingga baik untuk digunakan sebagai media pembelajaran.

\section{Revisi Desain}

Setelah desain produk divalidasi oleh para ahli sehingga diketahui kelemahankelemahanya. Langkah selanjutnya adalah revisi desain yang bertujuan untuk 


\section{Formatif: Jurnal Ilmiah Pendidikan MIPA}

Vol. 9, No. 2, Juni 2019, pp. 117-130

p-ISSN: 2088-351X

e-ISSN: 2502-5457

DOI: http://dx.doi.org/10.30998/formatif.v9i2.2978

menyempurnakan kelemahan pada desain sebelumnya (Sugiyono, 2015: 302). Berdasarkan komentar atau saran dari tahap validasi desain maka dilakukan revisi dengan keputusan revisinya sebagai berikut.

Tabel 4. Keputusan Revisi dari Hasil Validasi Desain

\begin{tabular}{lll}
\hline \multicolumn{2}{c}{ Komentar/Saran } & \multicolumn{3}{c}{ Keputusan Revisi } \\
\hline Urutan atau sistematika penyajian & $\begin{array}{l}\text { Sudah direvisi dengan urutan teori perencanaan } \\
\text { materi direvisi kembali }\end{array}$ & pembelajaran, jenis-jenis pendekatan \\
& pembelajaran matematika, contoh perangkat \\
& pembelajaran matematika (pogram tahunan, \\
& program semester, silabus, RPP, Lembar Kerja \\
& Siswa). & \\
\hline Perlu dicantumkan tujuan & Sudah direvisi denan mencantumkan tujuan \\
pembelajaran dalam media & pembelajaran/capaian pembelajaran sebagai \\
pembelajaran & & berikut: Mampu merencanakan, \\
& mengimplementasi, dan mengevaluasi \\
& pembelajaran matematika secara inovatif dengan \\
& mengaplikasikan konsep pedagogik-didaktik \\
& matematika dan keilmuan matematika serta \\
& memanfaatkan berbagai sumber belajar dan \\
& IPTEKS yang berorientasi pada kecakapan hidup. \\
\hline
\end{tabular}

Mencantumkan daftar pustaka di Sudah direvisi pada materi sudah dicantumkan akhir penyajian materi daftar pustaka atau referensi pendukung.

Ditambahkan evaluasi agar dapat Sudah direvisi pada setiap topic atau materi mengukur kemampuan atau pembelajaran diakhiri dengan evaluasi.

pencapaian mahasiswa

pembelajaran

Materi tidak hanya dapat dilihat tetapi dapat diunduh oleh pengguna

Disajikan video pembelajaran yang menggambarkan pendekatan pembelajaran matematika

Ditambahkan beberapa video pembelajaran sebagai ilustrasi beberapa pendekatan pembelajaran matematika

Media pembelajaran perlu
diperkaya dengan ilustrasi musik/sound
Sudah direvisi, pada setiap konten yang terdapat pada media pembelajaran dapat diunduh oleh pengguna.

Sudah ditambahkan beberapa video pembelajaran yang meliputi video pembelajaran penerapan pendekatan matematika.

Sudah menambahkan beberapa video
pembelajaran matematika (pendekatan kontekstual, pendekatan matematika realistik indonesia, pendekatan saintifik).

Sudah ditambahkan dengan ilustrasi musik/sound effect

Berdasarkan uji dua ahli, jika masing-masing skor dibuat persentasenya, maka presentase penilaian ahli materi sebesar $80 \%$ artinya sudah berada di atas indikator keberhasilan. Sedangkan presentase penilaian dari uji ahli media sebesar $75 \%$ artinya sudah berada diatas indikator keberhasilan. 
Formatif: Jurnal Ilmiah Pendidikan MIPA

Vol. 9, No. 2, Juni 2019, pp. 117-130

p-ISSN: 2088-351X

e-ISSN: 2502-5457

DOI: http://dx.doi.org/10.30998/formatif.v9i2.2978

\section{Uji Coba Produk}

Uji coba produk dilakukan dengan tujuan untuk mendapatkan informasi apakah produk yang dihasilkan efektif dan efisien untuk membantu proses pembelajaran. Dalam penelitian ini uji coba desain akan dilakukan melalui uji coba produk oleh user (uji terbatas), dalam hal ini terdiri atas calon guru matematika jurusan pendidikan matematika Untirta sebanyak 30 subjek.

Berdasarkan angket tertutup penilaian respon calon guru matematika maka produk media pembelajaran yang dikembangkan memiliki presentase penilaian sebesar $82,04 \%$ dengan klasifikasi kuat. Hasil dari angket terbuka calon guru matematika pada aspek kemenarikan media, kemudahan media, dan motivasi calon guru matematika terhadap penggunaan media pembelajaran menyatakan bahwa media pembelajaran perangkat pembelajaran matematika menarik karena dapat diakses menggunakan telepon genggam, pemilihan warna kontras, dan mudah dipahami. Responden juga menyatakan senang belajar dengan media pembelajaran pada mata kuliah perencanaan pembelajaran matematika, karena merasa lebih menyenangkan daripada belajar dengan buku. Selain itu responden menyatakan bahwa penyajian materi sudah jelas dan contoh-contoh penerapan pendekatan pembelajaran matematika sudah sesuai dengan materi yang disajikan.

\section{Revisi Produk}

Revisi produk dalam tahap ini dilakukan jika pada tahap uji coba produk terdapat kekurangan yang mengakibatkan kurang efektifnya penggunaan media pembelajaran berbasis Content Management System (CMS). Berikut media pembelajaran hasil revisi produk yang dikembangkan.



Gambar 3. Tampilan media pembelajaran 
Formatif: Jurnal Ilmiah Pendidikan MIPA

Vol. 9, No. 2, Juni 2019, pp. 117-130

p-ISSN: 2088-351X

e-ISSN: 2502-5457

DOI: http://dx.doi.org/10.30998/formatif.v9i2.2978

\section{Pembahasan}

Perangkat pembelajaran matematika merupakan suatu perangkat yang dipergunakan dalam proses belajar mengajar pada mata pelajaran matematika. Setiap guru pada satuan pendidikan berkewajiban menyusun perangkat pembelajaran yang berlangsung secara interaktif, inspiratif, menyenangkan, dan memotivasi siswa untuk berpartisipasi aktif (Devi, 2009). Perangkat pembelajaran yang diperlukan dalam mengelola proses belajar mengajar dapat berupa: program tahunan, program semester, silabus, RPP, LKS, Modul, instrumen evaluasi, dan rubrik penskoran.

Betapa pentingnya ketersediaan perangkat pembelajaran, sehingga calon guru matematika perlu dibekali kemampuan dalam merancang perangkat pembelajaran. Untuk menumbuhkan pemahaman dan mendorong kemampuan calon guru dalam merancang perangkat pembelajaran, salah satunya diperlukan media pembelajaran yang dapat diakses oleh calon guru, tidak hanya dalam proses pembelajaran, tetapi dapat diakses tanpa terbatas ruang dan waktu. Salah satu yang dapat dimanfaatkan adalah jasa internet.

Hasil survei yang dilakukan Asosiasi Pengusaha Jasa Internet Indonesia (APJII) bersama PUSKAKOM UI tahun 2014 (Goenawan, 2015) menunjukan bahwa 88,1 juta masyarakat Indonesia aktif menggunakan jasa internet. Hal yang menarik dari rilis survei ini adalah pengguna usia 18-25 tahun yang terbanyak menggunakan jasa internet. Menyusul usia 26-35 tahun sebesar 33,8\%, 36-45 tahun sebesar 14,6\% dan terakhir usia 56-65 tahun sebesar 0,2\%. Ini berarti generasi yang lahir tahun 80 -an atau dikenal dengan "generasi Milenia" mendominasi penggunaan internet, karena masa inilah penggunaan internet semakin marak, mudah, dan murah. Dari 7.000 responden yang disurvei, terdapat $85 \%$ diataranya mengakses internet melalui telepon genggamnya, mengungguli penggunaan internet malalui laptop, PC maupun tablet. Hasil penelitian tersebut sejalan dengan hasil observasi yang dilakukan Sudiana (2014) yang menunjukan bahwa menunjukan 91\% mahasiswa di jurusan pendidikan Matematika Universitas Sultan Ageng Tirtayasa aktif menggunakan internet sebagai media komunikasinya. Hal lain yang memperkuat media pembelajaran berbasis internet adalah hasil studi literatur beberapa penelitian melaporkan bahwa buku teks belum optimal sehingga bahan ajar interaktif dapat membantu siswa untuk aktif, mandiri dan bertanggung jawab dalam proses pembelajaran (Rafianti, 2018).

Arsyad (2010) menyatakan bahwa perkembangan ilmu pengetahuan dan teknologi semakin mendorong upaya-upaya pembaharuan dalam pemanfaatan hasil-hasil teknologi dalam proses belajar. Dengan perkembangan teknologi yang ada, berkembang media pembelajaran yang memanfaatkan dua unsur atau lebih media yang di antaranya adalah teks, gambar, audio, video, dan animasi secara terintegerasi. Media pembelajaran ini dikenal dengan istilah multimedia pembelajaran. Menurut Gayestik (Soenarto, 2005) multimedia sebagai suatu sistem komunikasi interaktif berbasis komputer yang mampu menciptakan, menyimpan, menyajikan, dan mengakses kembali informasi berupa teks, grafik, suara, video atau animasi. Senada dengan hal tersebut Turban, (2002) mendefinisikan multimedia sebagai alat yang dapat menciptakan presentasi dinamis atau interaktif yang mengombinasikan teks, grafik, animasi, audio, dan gambar video (Robin, 2001). Mccauley (2000) melaporkan bahwa multimedia menyediakan informasi untuk peserta didik secara sederhana dengan jalan bagaimanapun, multimedia interaktif memberi kendali informasi kepada para pemakai dan memastikan keikutsertaan mereka. Heinich (2002) juga menguraikan multimedia interaktif sebagai multimedia yang mengizinkan para peserta didik untuk membuat implementasi dan menerima umpan balik (Arkan \& Akkoyunia, 2008). Dengan multimedia pembelajaran, proses pembelajaran diharapkan menjadi lebih menarik, interaktif, jumlah waktu mengajar dapat dikurangi, 


\section{Formatif: Jurnal Ilmiah Pendidikan MIPA}

Vol. 9, No. 2, Juni 2019, pp. 117-130

p-ISSN: 2088-351X

e-ISSN: 2502-5457

DOI: http://dx.doi.org/10.30998/formatif.v9i2.2978

dan proses belajar dapat dilakukan di mana saja dan juga kapan saja. Salah satu aplikasi yang dapat dimanfaatkan dalam pengembangan media pembelajaran adalah CMS.

Menurut Gunardi dan Lirva (2007) CMS bisa didefinisikan sebagai pengelolaan isi atau content. Bila dikaitkan dengan web, maka CMS bisa didefinisikan sebagai software yang mampu mengelola isi atau konten dari sebuah website seperti melakukan publikasi, edit ataupun menghapus sebuah konten. Lebiih lanjut, CMS adalah sebuah sistem yang memberikan kemudahan kepada para penggunanya dalam mengelola dan mengadakan perubahan isi sebuah website dinamis tanpa sebelumnya dibekali pengetahuan tentang hal-hal yang bersifat teknis, dengan berbagai keuntungan yang dimiliki CMS. Terdapat beberapa keuntungan dalam menggunakan CMS antara lain (1) Dapat menampilkan informasi yang terbaru, konsisten, dan berkualitas, (2) Memiliki fasilitas yang dapat memanfaatkan kembali konten yang sudah ada, (3) Meningkatkan produktivitas dan kepuasan sebuah tim (web programmer, web designer, web administrator), (4) Pembuatan server dapat dilakukan secara desentralisasi (dilakukan oleh berbagai orang dari berbagai tempat), (5) Memiliki fasilitas untuk mendefinisikan alur kerja sebuah tim dan melakukan pengaturan terhadap proses approval dan pengaturan lainnya (Iqbal, 2009).

WordPress termasuk ke dalam kelompok aplikasi CMS. Wordpress adalah sebuah aplikasi sumber terbuka (open source) yang sangat populer digunakan sebagai mesin blog (blog engine). WordPress dibangun dengan bahasa pemrograman PHP dan basis data (database) MySQL. PHP dan MySQL, keduanya merupakan perangkat lunak sumber terbuka (open source software).

Aplikasi CMS wordpress sebagai media pembelajaran berbasis teknologi informasi komunikasi (TIK) memberikan kontribusi positif kepada peserta didik, mengingat media pembelajaran tersebut dapat diakses oleh peserta didik tanpa terbatas ruang dan waktu. Menurut Alessi dan Trollip (Darmawan, 2016) "Pembelajaran berbasis TIK memiliki banyak keunggulan. Salah satunya, keunggulan itu berupa penggunaan waktu yang digunakan menjadi lebih efektif, bahan materi pelajaran menjadi lebih mudah diakses, menarik, dan murah biayanya. Hasil penelitian Marasut (2012) menunjukkan rata-rata hasil belajar kelompok siswa yang mengikuti pembelajaran matematika dengan menggunakan aplikasi teknologi informasi dan komunikasi yang berbasis internet lebih tinggi dibandingkan dengan kelompok siswa yang mengikuti pembelajaran ekspositori untuk semua materi pembelajaran yang diprogramkan dalam penelitian ini. Gaynor (2005) menjelaskan TechWatch anticipates developments in information and communication technologies that might have high impact on the core business of further and education (teaching and learning) in five to ten years' time. Lebih lanjut hasil penelitian Rusmana (2012) menunjukkan bahwa terdapat pengaruh yang signifikan antara penggunaan media TIK terhadap pemahaman konsep matematika.

Berdasarkan hasil penelitian yang ditunjang kajian peneltian-penelitian yang ada, maka media pembelajaran CMS perangkat pembelajaran matematika bagi calon guru matematika layak digunakan pada mata kuliah kependidikan, salah satu di antaranya adalah mata kuliah perencanaan pembelajaran matematika.

\section{PENUTUP}

Dari hasil penelitian dan pembahasan, dapat disimpulkan bahwa hasil penilaian dari ahli dan responden yaitu sebesar $83,8 \%$ artinya sudah memenuhi indikator keberhasilan dari produk yang dikembangkan. Adapun saran kepada peneliti lainnya agar dapat mengembangkan media pembelajaran lain dengan memanfaatkan software lain 


\section{Formatif: Jurnal Ilmiah Pendidikan MIPA}

Vol. 9, No. 2, Juni 2019, pp. 117-130

p-ISSN: 2088-351X

e-ISSN: 2502-5457

DOI: http://dx.doi.org/10.30998/formatif.v9i2.2978

yang lebih kreatif serta inovatif agar dapat menarik perhatian dan memunculkan motivasi belajar serta memudahkan calon guru matematika dalam merancang perangkat pembelajaran matematika.

\section{DAFTAR PUSTAKA}

Arkan, dan Akkoyunia. (2008). A study on the development process of a multimedia learning environment, according to the ADDIE model and students opinions of the multimedia learning enviroment. Interactive Educational Multimedia: University of Barcelona, 10 (17): 1-19.

Arsyad, A. (2010). Media Pembelajaran. Jakarta: Rajawali Pers.

Astuti, D.P., Leonard, L., Bhakti, Y. B., \& Astuti, I. A. D. (2019). Developing Adobe Flash-based mathematics learning media for $7^{\text {th }}$-grade students of junior high school. Journal of Physics: Conf. Series 1188012098. http://dx.doi.org/10.1088/1742-6596/1188/1/012098

Darmawan, H. (2016). Pembelajaran berbasis konstruktivisme menggunakan media animasi dengan kerangka kerja TPCK dan gaya belajar terhadap prestasi belajar siswa. Formatif: Jurnal Ilmiah Pendidikan MIPA, 6 (1): 1-11.

Depdiknas. (2007). Permendiknas Nomor 41 Tahun 2007 Tentang Standar Proses. Jakarta: Kementrian Pendidikan Nasional.

Devi, P. K. (2009). Pengembangan Perangkat Pembelajaran. Bandung: P4TK IPA

Gaynor, H. $2005 . \quad$ Technology Watch. Http://Www.Jiscmail.Ac.Uk/Cgibin/Webadmin?A0=Jisc-Tsw.

Goenawan. (2015). Generasi Millenial Kuasai Internet Indonesia. Tersedia pada: Http://Inet.Detik.Com/Read/2015/03/26/192817/2870859/398/Generasi-

Millenial-Kuasai-Internet-Indonesia. (Online). 20 Januari 2018.

Gunardi, I, M., dan Lirva. (2007). Joomla Website Magic: Dengan Joomla Bikin Website Semudah Memasak Mie Instan. Jakarta: Jasakom.

Hamzah, A. \& Muhlisrarini. (2014). Perencanaan dan Strategi Pembelajaran Matematika. Jakarta: PT Rajagrafindo Persada.

Henich, R. et al. (2002). Instrucional Media and Technology for learning, $7^{\text {th }}$ edition. New Jersey: Prentice Hall. Tersedia pada: http://books.google.co.id. Diakses 10 Maret 2018.

Iqbal. (2009). Rekayasa content management system (CMS) joomla berbasis open source untuk pengembangan sistem informasi berbasis online. Jurnal Informatika, 3(1): 297-303.

Kemdikbud. (2014). Permendikbud Nomor 59 Tahun 2014. Jakarta: Kementrian Pendidikan dan Kebudayaan.

Kunandar. (2007). Guru Profesional (Implementasi Kurikulum Tingkat Satuan Pendidikan dan Sukses dalam Sertifikasi Guru. Jakarta: PT Rajagrafindo Persada.

Majid. A. (2013). Strategi Pembelajaran. Bandung: PT. Remaja Rosdakarya.

Marasut, A. (2012). Penggunaan media teknologi watch dalam pembelajaran matematika di SMA Kristen Irene Manado. Formatif: Jurnal Ilmiah Pendidikan MIPA, 2(1): $1-9$.

McCauley, E., Mitchell, J. R., Burke, P., \& Moss, S. (1988). Cognitive attributes of depression in children and adolescents. Journal of Consulting and Clinical Psychology, 903-908. 
Formatif: Jurnal Ilmiah Pendidikan MIPA

Vol. 9, No. 2, Juni 2019, pp. 117-130

p-ISSN: 2088-351X

e-ISSN: 2502-5457

DOI: http://dx.doi.org/10.30998/formatif.v9i2.2978

Rafianti, I, dkk. (2018). Pengembangan bahan ajar interaktif tutorial dalam pembelajaran matematika siswa SMP. Jurnal Penelitian dan Pembelajaran Matematika, 11(2): $119-128$.

Riduwan. (2010). Belajar Mudah Penelitian untuk Guru, Karyawan, dan Peneliti Pemula. Bandung: Alfabeta.

Robin, L. (2001). Menguasai Pembuatan animasi dengan Macromedia Flash. Jakarta: Elek Media Komputindo.

Rolisca, R,U,C. Achadiyah, B,N. (2014). Pengembangan media evaluasi pembelajaran dalam bentuk online berbasis e-learning menggunakan software wondershare quiz creator dalam mata pelajaran akuntansi SMA Brawijaya Smart School (BSS). Jurnal Pendidikan Akuntansi Indonesia, XII (2): 41-48.

Rusmana, I. M. (2012). Efektivitas penggunaan media ICT dalam peningkatan pemahaman konsep matematika. Formatif: Jurnal Ilmiah Pendidikan MIPA, 2(3): 198-205.

Sudiana, R. (2014). Pemanfaatan media sosial sebagai sarana penunjang perkuliahan di jurusan pendidikan matematika. Laporan Penelitian: Serang: Untirta.

Sugiyono. (2010). Metode Penelitian Pendidikan Pendekatan Kuantitatif, kualitatif, dan $R \& D$. Bandung: Alfabeta.

Sugiyono. (2015). Metode Penelitian Kombinasi (Mix Methods). Bandung: Alfabeta.

Soenarto, S. (2005). Model Pembelajaran Berbasis Komputer. Makalah Disajikan Dalam Pelatihan Model Pembelajaran PBK, Tanggal 26 - 28 November 2005, Di P3AI UNY.

Susilo, M. J. (2007). Kurikulum Tingkat Satuan Pendidikan. Yogyakarta: Pustaka Siswa.

Tim Puslitjaknov. (2008). Metode Penelitian Pengembangan. Balitbang Diknas. Jakarta.

Turban., dkk. (2002). Aplikasi Multimedia Interaktif. Yogyakarta: Paradigma. 